Csehy Zoltán

Comenius Egyetem, Pozsony

\title{
A térré lett idő
}

\section{Metaforikus és konkrét térátlépési stratégiák a modern klasszikus zenében, különös tekintettel a lírai szövegek metamorfózisaira}

„A zene egyik legdöntóbb jelentôségú tényezóje az idō. Harmónia nélküli zene elképzelhetó (ilyen például az egyszólamú népzene), dallam nélküli zene is van (ilyen például a jazz

ütóhangszer-improvizációja), de olyan zene, melynek ne lenne idôtartama, nincsen” - írja Pongrácz Zoltán (1971, 89. o.). A zenei tér hosszú ideig leginkább akusztikus térként, úgynevezett átviteli

közegként játszott kiemelten fontos szerepet: "hangszerként”, "tényezóként" való megszólaltatása elsósorban a modern kor érdeme. Ligeti György ugyancsak erre a zenetörténeti tapasztalatra hívja fel a

figyelmet: a zenei tér elsôsorban a „hangvisszaadás minósége” szempontjából játszott szerepet, nem pedig a formai-tartalmi vagy befogadói-értelmezói aspektusok felól. Sót, még azt a kijelentést is megkockáztatja, hogy: „Az olyan zene hallgatásakor, amelyet a harmóniai kapcsolatok logikája ural, a forma idóbeli elórehaladása annyira igénybe veszi a figyelmünket, hogy a tér, amelyben ez az idóbeli vándorlás végbemegy, eltúnik elólünk” (Ligeti, 2010, 184. o.).

A tér-zene-tapasztalás (Wörner, 2007, 609. o.) poétikai lehetőségeinek tudatos kiaknázása a huszadik század zenéjében egyre fontosabbá válik: a térinstallációs stratégiák legkülönfélébb megvalósulásai egyre jelentékenyebben szólnak bele a zene önazonosságának megképződési folyamatába. A térátlépési stratégiák között alapvetően két irányulás, illetve azok dinamikája érvényesül.

Az első tendencia a koncertterem (az ideális akusztikus tér) defetisizálásával függ össze. A terem totális hangzástérré válik, ahogy a hangszer térbeli materialitása is ,,szóhoz jut”, hiszen az eddig csak ,normatív” hangzások előcsalogatására alkalmas eszköz immár gyakorta totális zenei konfigurációként értelmezhető tárgyként jelenik meg (azaz „,nem rendeltetésszerúen” is megszólaltatható). A zene kilép a neki szentelt „szakrális” térből, Cage szétülteti zenészeit, hangzó szigetek jönnek létre, osztott hangszórócsoportok lépnek müködésbe stb. Ez sokféleképp realizálódhat: jellemző stratégia a befogadó és elöadó tereinek kölcsönös, tudatos „megsértése” (pl. Stockhausen, Eötvös munkáiban), a zene kimenekítése a természetes térbe, illetve szokatlan térben való észlelése (pl. Cage egyes müveiben), esetleg extrém terek hangzáseffektusainak kiaknázása (pl. Stockhausen: Helikopter-kvartett). Ligeti $(2010,186$. o.) a „térbeli zene” felfutásának okát az elektroakusztikus apparátus felfejlődésével magyarázza, s a zene e létmódja már ,a hangzások térbeli artikulációját a forma lényeges elemeként" érvényesíti.

A másik tendencia összetettebb mechanizmusokon alapszik, hiszen eredendően térarchitektúrák zenei leképezéséről van szó. A zenei ekphraszisz müfaja egy-egy térbeli 
anyagisággal rendelkező műalkotás (szobor, festmény, épület) zenébe írásából áll. De lehetséges olyan változata is, melynek során a müvész eleve hangszobrokat hoz létre, s a térbeliség nem origója, hanem megvalósulása, szerves komponense a mủalkotásnak (pl. Bill Fontana hanginstallációi).

A térarchitektúrák leképezése kompozíciós effektusokban is megnyilvánulhat: egyszerü példa a grafikus zene, kottából grafikába és fordítva megvalósuló térátlépés, az egyes hangszercsoportok, zenészek vizuális vagy térpoétikus elhelyezése (Stockhausen

Az elsó tendencia a koncertterem (az ideális akusztikus tér) defetisizálásával függ össze. A terem totális hangzástérré válik, ahogy a hangszer térbeli materialitása is „szóhoz jut”, hiszen az eddig csak "normativ" hangzások elócsalogatására alkalmas eszköz immár gyakorta totális zenei konfigurációként értelmezhetó tárgyként jelenik meg (azaz „nem rendeltetésszerüen” is megszólaltatható).

A zene kilép a neki szentelt „szakrális” térból, Cage szétülteti zenészeit, hangzó szigetek jönnek létre, osztott hangszórócsoportok lépnek müködésbe stb. Ez sokféleképp realizálódhat: jellemzó stratégia a befogadó és elöadó tereinek kölcsönös, tuda-

$$
\text { tos „megsértése” (pl. }
$$

Stockhausen, Eötvös munkáiban), a zene kimenekitése a természetes térbe, illetve szokatlan térben való észlelése (pl. Cage egyes müveiben), esetleg extrém

terek hangzáseffektusainak kiaknázása (pl. Stockhausen: Helikopter-kvartett).

A tárgy térbelisége tudatosan kelthet zenei hatást: a kínai Huainanban található Piano-house egy szárnyas zongora alakú építmény, melynek oldalához egy hegedü támaszkodik. A hegedű testén keresztül lehet feljutni a zongorába, s mintegy beférkőzni a hang[1992] Szombat címü operájában pl. Lucifer 25 méteres arcát a zenekar elhelyezkedése formázza meg, pl. a bal szemöldököt egy ütős, két kolompos és nyolc erdei kürtös alkotja, és így tovább).

„A münek magában kell foglalnia a környezetét, mindig kísérleti jellegü (haladási iránya ismeretlen)" - írja Cage (1994, 199. o.). Ez a környezettudatos kontextualizálás nem pusztán a zenei befogadás során kialakuló valóságos és asszociatív térképzetek felerősítésekor érvényesül, hanem a zaj, a zörej, a csönd, az elhallgatás megjelenítésekor is müködőképes, sőt olykor a müalkotás létrejöttét is megakadályozhatja vagy felszámolhatja. A hangerőhöz társított közelséget, távolságot, a rezgési idő érzékeléséből fakadó mélység- és magasságérzetet, a hanglétra, a lépcső (skála) térképzeteit minden zenehallgatás eleve aktiválja. A tér azonban konstitutív erőként kezd el funkcionálni már Webern zenéjében is: Ligeti $(2010,188$. o.) kiemeli, hogy „Webern zenéjében majdnem teljesen megtörténik az időfolyamat kivetülése [...] a képzeletbeli térbe, mégpedig a motívumalakok és megfordításaik állandóan jelenlévő kölcsönössége révén", hiszen nála a térbeli visszatérés kerül az időbeli visszatérés lehetetlenségének helyére, s a korábbi vagy későbbi mint világos időkategória elveszti a jelentőségét. Ide sorolhatóak továbbá a metaforikus térkezelés olyan esetei is, mint amilyen pl. Zimmermann térbe robbanó időkezelése, melynek során az időstruktúra gömbszerü térképződménnyé alakul át, vagy a klasszikus angyaltest-hangszer metafora. A hangzástömbök aránytani, térmértani meghatározottsága, architektúrája (pl. Xenakis munkáiban) hasonlóan eredeti utat jelent. 
szerház belső világába. Az éktelen giccs világosan figyelmeztet a funkcióra, ugyanakkor az épület épp kárhozatos harsánysága miatt nem szólalhat meg. Az építészeti megfontolás térpoétikája komolytalanná degradálja a vállalkozás esztétikai programját. Ha viszont a Los Angeles-i Walt Disney Concert Hall épületegyüttesét nézzük, a tér „,zeneisége” kelt elemi hatást: Esa-Pekka Salonen Wing on Wing címü szimfonikus költeménye lényegében az épület zenébe írása. A címben szereplő szárny amellett, hogy Corinna Hesse értelmezése szerint elsősorban hajózási terminus, mely a szélerő befogásának legjobb módját jelöli (Salonen, 2005), nemcsak angyal-, hanem épületszárnyat is sejtet: a zene áhítatos és titokzatos jellege mellé (ezt a két szopránszóló megjelenése is fokozza) a hajózás allegorikus értelmezéstömkelege zárkózik fel. A 25 és fél perces zenemü a koncertterem építője, Frank O. Gehry művészete előtt tiszteleg. Az építész megszólaltatott, modifikált hangja, mondhatnánk kissé patetikusan, lényegében a beavatott odüsszeuszi emberé, aki a technikai csábítás szirénjei közt hajózott ki a kreativitás tengerére. Az általa tervezett épület a hullámverést, a morajló tengert, az áramlást, magát a tárgyiasult kihívást idézi, egyike a kortárs építészet vitathatatlan remekléseinek. A zene kettős térképzetet kelt: az épület fizikai és metaforikus valóságáét. A mű felénél zenei lépcsőfokok sokaságát érzékeljük, vagy ha tetszik, a tudat megnyíló örvényeit, melyek az emberi hang zsongásában és az angyali szférát megidéző harangkondulásban oldódnak fel. Az örvénylés, a fokozás, a felismerés, a tudatosulás és a rácsodálkozás gesztusrendszereit müködteti. A szirénhangok eltünése és felbukkanása a víz ősprincípiumának kiemelésére is szolgál. Már Horatius kikel egy ódájában a tenger istenét hajókkal háborgató ember önhitt tudásvágya és világhódító birtokvágya ellen, s rámutat a hajózás technikai tökélyének látszatos mivoltára. Salonen ezért is rendeli az építész munkája mellé az angyalokat, a misztika mellé a szakrális tudást. A szirének csábítása az önpusztítást is megidézi, de a heroizmus lehetőségét is magában hordozza. A fantázia lényeinek megjelenését ellenpontozza az emberi hang tagoló jelenléte és egy dél-kaliforniai halfajta félelmetes hangjának belekomponálása a mübe: az ember pozíciója köztes, ő már kilépőben van a természetből, ő már a technikai világ univerzumában él, s erre a szinte akváriummá változó épületben megelevenedö, éneklő hal döbbenti rá.

A zenei lejegyzés konvenciói régóta lehetővé teszik egy-egy személy nevének zenébe írását: ez hagyományosan is megtörténhet, mégpedig a notáción, a konvencionális jelrendszeren belül. A notáció és a zenei grafika (egyszerüsítve: egyértelmü jel és asszociatív kép) elkülönítését Ligeti György végezte el, noha elismeri, hogy a két technika időnként találkozik. A notáció jelrendszer, mely a zene létrejöttét eredményezi, zenei viszonyokat ír le, a zenei grafika ezzel szemben nem alkot jelrendszert, ugyanakkor ábrázolhat olyan folyamatokat, melyek az asszociatív alapú zene létrejöttéhez elengedhetetlenek, ám a zenei grafika nem transzformálható, értéke „,saját magában van: abban, hogyan jelenik meg mint esztétikai tárgy, és hogy milyen minőségü mint vizuális alakzat" (Ligeti, 2010, 199. o.).

Van olyan eset is, tehetnénk hozzá, amikor egy partitúra notáció és grafika felőli kettős olvasata teljesen egyenértékü. Sylvano Bussotti Raragramma című opusának partitúrája lényegében a RARA szó színes grafikai megjelenítése a kottavonalak terében: a partitúra itt tehát nem pusztán hanganyag, hanem egyúttal látványos, színes kép is. Itt létezik hagyományos értelmü notáció is és grafika is: a látványban létező kép a megszólalás maga, a zenébe írt név a notációban bujkáló grafika. Szemléletes és célirányos lejegyzés alakul át hangzáson túli képpé, egy a zenei narratíván élösködő képi hipernarratíva válik itt világossá. Bussotti természetesen inadekvát notációt is alkalmaz (Pieces de chair II.), illetve látszólagos mintázatok nyomán generál grafikus értelemben ihlető forrást, mely alapján a zenész komponálja meg a müvet, melyet aztán akár hagyományos(abb) notációval is le lehetne jegyezni. A zenei grafika lényegében architextuálisan a notációra vezethető vissza, de térfoglalási agresszivitásának köszönhetően kisebb-nagyobb mértékben fel is számolhatja azt. 
A kép lehet grafikaként, vizuális kompozícióként értelmezett partitúra, illetve (mint Stockhausennel kapcsolatban említettük) a zenei megvalósulás folyamatában kialakított tárgy. „Cage partitúrái olyan zseniálisak, olyan gyönyörüen cirkalmasak voltak, hogy múzeumokban állították ki öket" - írta H. C. Schonberg (2006, 632. o.).

A zene képpé válásával ellentétes irányú folyamat a kép vagy tárgy zenévé válása. John Cage híres Atlas Eclipticalis címü müve pl. a csillagtérkép (Antonín Becvár cseh csillagász 1958-as atlasza) és a kotta, illetve a zenei notációra használt papír mintázatainak egybejátszásán alapszik, de olyan kompozíció is született, mely közvetlenül a notációs papír hibáira épül. Cage Ryoanji címü müvének alapgondolata a tér zenei transzformációja: a zeneszerző által észlelt 15 kő átrajzolásán alapszik.

A lírai szöveg helyzete zenei térben különösen bonyolult a térátlépési stratégiák tükrében.

Nemegyszer a lírai szöveg elveszti önazonosságát, önmagán túli jelentésekkel telítődik - a zenei tér felemészti, amennyiben a lírai szöveg különösen ,agresszív” zenei térbe kerül. Morton Feldman (2000) Neither címü operája például teljes egészében felemészti, szótagfoszlányaira bontja Samuel Beckett librettóját: egy tizenhat soros verset. A darab és a vers is az identitás és az árnyékidentitás, külső és belső árnyak, érzékletek analízisével foglalkozik. A kimondhatatlanság, az én otthontalansága, kirekesztettsége idegen térbe helyezve abszolút kiszolgáltatottjává válik az érzéki észleleteknek, benyomásoknak, melyek az opera belső cselekményét döntő részt kiteszik. Beckett verse szinte szótagokra, hangokra lebontva jelenik meg az opera egyes részein. A mü kíméletlen ismétlések és sokszor egyenesen monoton, lassan mozduló modifikációk sorozata: egy-egy tonális gesztus lebontásának folyamata a szoprán szöveglebontó tevékenységével összhangban nyúlik az elviselhetőség határáig. A szöveg egésze a hallgató számára kevéssé észlehető, annak hangulata és rejtett tartalmai viszont annál inkább feltárulkoznak előtte: az intimitás pőresége valóban sokkoló erejü lehet, ha megfelelő rendezői koncepcióval párosul. Az időnként depresszív, halk dinamikájú, máskor kifejezetten hipnotikus erejü, éterinek hangzó zene egyszerre nyújt kommentátori teret a lényegében értelmileg érzékelhetetlen szöveghez, és egyszerre kebelezi be, avatja önnön terének tájékozódási pontjaivá a roncsolt fragmentumokat.

„én azt szeretném, ha minden darabom egyforma volna, de hiányzik belőlem az ehhez szükséges önfegyelem. Azt szeretném, ha darabjaim mindig ugyanazt a területet járnák be. Egyetlen új hangszer belépése már mindent megváltoztat" - nyilatkozta Feldman (Varga, 1986, 120. o.)

A Neither egy lelkiállapot-kiáradás, mely a belső koncentráció diadalaként analizál egy bonyolult, teljességgel mindvégig kiismerhetetlen tudattartalmat, de hát a határozatlanság, a döntésképtelenség lírai elemzése eleve nem is járhat túlságosan határozott felismerésekkel. A darabot az indeterminizmus jellemzi: célja egy új időérzet megteremtése a mü megszólaltatási módjainak felszabadítása, valamint a hangok, struktúrák egymástól való függetlenítése révén. Az azonosíthatóság hiányának poétikus és teremtő energiát tulajdonító zeneszerzők a közömbös külvilág véletlen zaj- és zenei effektusai felé fordulnak, miközben a forma teljes egészében megnyílik, és felszámolja zenetörténeti beágyazottságát.

A szöveg primátusának megszüntetése, a konkrét jelentés helyett asszociatív/érzelmi/ metaforikus oldódás, beleveszés korábban is ismert stratégiának számított: „A 20. század első felében született vokális müvek túlnyomó részében a szerzők továbbra is a »szövegmegzenésítés« feltétlen elvéhez ragaszkodnak: a jelentést hordozó hangzókat egy vagy több, pontosan rögzített hangmagasságban énekelendő hangnak feleltetik meg" - írja Wörner (2007, 582. o.), majd felhívja a figyelmet a schönbergi énekbeszédre, illetve a 
Debussy-féle „boccachiusa dalra”, melyben a zeneszerző a szótestekből csak a magánhangzókat használja fel. A szöveg elsősorban zenei konstelláció lesz, „hanganyag”, formai értelemben azonban térmeghatározó is lehet (pl. antitetikus szerkezetek, szólamszabályozás, repetitív gesztusok) - a zenei tér materializálja, anyagi összetevőire bontja, majd fokozatosan saját részévé teszi. A szövegszerkezet maradhat érintetlen akkor is, ha a zenei tagolás radikalizmusa eltávolítja az elvben szabályos szótagszekvenciákat egymástól, és az az értelem rovására történő csonkolásnak hat. A fonetikus beszéd és zenei szerkezetek érzelmi töltete között kialakuló dinamika végletekig fokozása a szóérthetőség megszüntetése (pl. Feldman, Nono müveiben), melyből egyenesen következik a sorrend megbontása, illetve az egyes elemek egyidejü egymásra rétegződései. Az új értelem egy új, fonetikusan strukturált, nyelv fölötti nyelvet konstruál (pl. Ligeti: Aventures, Nouvelles Aventures). A térbeli artikuláció formakomponenssé válik, a hang pedig nyelvként müködik, miközben a nyelv hanggá, univerzális jellé alakul. A szemantikai helyére az affektív lép: Feldmannál nem a vers válik operává, hanem az opera játszódik le a versben.

Ugyanakkor a lírai szöveg rejtett tartalmainak felfedése (értelmi szempontból akár) továbbra is lehet zeneszerzői feladat. Ilyenkor a szöveg a zenei térben lepleződik le, mint pl. Eötvös Péter Atlantis címü müvében Weöres Sándor kriptogrammája:

„a látATLAN TISZta világért

mely nem az évekkEL SÜLLYEDT habokba a redőtlen szerelMI KORszakért ami folyton elsötétült

így szülte a TÖRT ÉNT a világtalant s a törzs NEM IS MERI egymásban feloldani többé

a semmiből éleSEN KIált"

Eötvös egy bariton és egy fiúszoprán egybehangzó duettjeként szólaltatja meg a szövegrészt: a törzsszöveget a férfi, a kriptogrammát a fiú énekli. Az első tételben szereplö, értelmi egységekbe nem szerveződő szótagok érteleminváziója ez, a szöveg genézisének kozmológiája. Ez a teremtődés-állapot a teremtődő értelem mindenkori egyértelmüsíthetőségének katasztrófája is.

A zenei tér a zenés színházban kezdettől érvényesül: ez a színházi tér részint összmüvészeti jellegü, részint (történeti értelemben) a számüzetés helye (nem vokális müvek esetében). A lírai szövegek operai térbe kerülve epikásodásnak indulnak: a zenei/drámai tér természetszerüleg hipernarratívába szervez „független” szövegeket is. A lírai szöveg ilyenkor önmagán túli dimenziókat nyer, s önazonossága az oldódó függetlenségből átcsúszik a zenedrámai konstellációba. E szövegek - Lawrence Kramer fogalmával élve - hermeneutikai ablakokként funkcionálnak, melyeken keresztül a zenéből kilátni a „társadalmi-szellemi valóságba" (Kodaj, 2005, 131. o.). A hermeneutikai ablakok hármasságából (textuális elemek, idézetek és utalások, strukturális trópusok) épp a szöveg tünhet a legegyértelmübben megragadhatónak. Kurtág György (1995) Keringő címü darabja például Pilinszky versmondásának sajátos kíséretévé válik: Pilinszky szavalata valójában a nyelv zenéje, a vers átlépése a zene terébe, miközben a (megkettőzött) zongora váratlanul a vers textusának és formájának megelevenedése lesz („A zongorát befutja a borostyán”).

A lírai szövegekből felépített hagyományos zenei/drámai/színházi térre szolgáljon példaként David Del Tredici Brother címü operája. ${ }^{1}$ Del Tredici múve nem vérbeli opera, sokkal inkább egy dramatizált, dramatizálható, nyolc szövegre épített dalciklus, noha a munkát a szerző maga is színpadi müvei közt tartja számon. John Kelly, az ősbemutató előadója és a szövegkönyv összeállítója négy saját, a meleg szerelmi és szexuális élet és a nagyváros viszonyát taglaló szubkulturális karakterü versét is beiktatta. Egy szerelmes homoszexuális férfi lelki világába nyerünk betekintést, a sötét bárok magányába, a meleg fürdők világába, a társadalmi elszigeteltség, a távkapcsolat kínjaiba. A 'brother' szó ero- 
tikus töltetet nyer, miközben összes más jelentésárnyalatát is megőrzi. Az első költemény (Kelly müve) irdatlan egocentrizmusával tüntet. A, Szerettem” tőmondattal induló és az „Élni fogok” fordulattal záruló vers izokólonok sorozata (minden sor azonos nyelvtani szerkezetü), mind a huszonnyolc sora az 'én' szóval kezdődik. A zenei térben idegesítően hangsúlyossá tett én lassan kivonja magát a koherensnek vélt identitás fennhatósága alól. Ezt egy Ginsberg-vers (Personal Ad) követi, mely lényegében egy hirdetés szövege: az én itt már határozott identitást kap, igaz, a megnyilatkozási formához illően stilizáltat. Kelly újabb versei következnek, melyek a létszorongatottságról éppúgy tudósítanak, mint a titkos szerelem körülményeiről: ,az ajtót jól bezárni, ez itt a szabály / elrejteni a szégyent / és visszafogni a számkivetettséget / egy fél órára / ebben a minimotelben / ebben a koszos sötét szobában". A koszos szoba titkos terét megjelenítő zene a zártság és a kontrollálhatatlan spontaneitás dinamikájára épít. Paul Monette költeménye (Here) egy döbbenetes sirató és kesergés az AIDS-ben elsorvadt partner (Roger Horowitz) halálán, Jaime Manrique verse pedig egy fiatalon, homoszexualitása miatt megkínzott és brutálisan megölt meleg fiú, Matthew Shepard (1976-1998) sorsán keresztül szembesít a huszadik század végén még mindig eleven homofóbia kérdéskörével. A privát tér társadalmi térré tágítása az én-ek felől elgondolt mi- és ők-struktúrák megkonstruálása miatt válik érdekessé. Matthew Shepard lelke a költeményben elhagyja a meggyötört testet és a mennybe szállva megdicsőül: a szakrális tér utalásos zenei megformálása ismét hermeneutikai ablakként funkcionál. A mü hetedik egységét Lewis Caroll Alíz Csodaországban címü müvének megidézése követi (Acrostic song), majd ismét Kelly-vers következik, méghozzá a címadó, fájdalmas hangú költemény. A földrajzi távolság miatti kesergés és a keserves nosztalgia, illetve könnyes emlékidézés kétségbeesett segélykiáltásként hat. A dal végén egy hang olaszul elszámol 1-től 13-ig (tredici), megidézve, illetve kimondva a zeneszerző nevét.

A lírai szöveg a leggyakrabban metaforikus zenei térbe kerülve nyer új egzisztenciát a lírai szöveg költői térképzeteket kelt, vagy ekpraszisz jelleget ölt, a metaforikus zenei tér és a szöveg ,terei” találkoznak.

Luigi Dallapiccola (2003) Ulisse címü operája, mely lényegében Kavafisz Ithaka címü versének szétírása és szétszálazása, Francois-Gildas Tual ötletes megfigyelése szerint a megfeszített íj ívéhez hasonlatos szerkezetet mutat, melynek két szélső feszpontja Kalüpszó lélegzetelállítóan szép nyitó áriája („son soli, un’altra volta”) és Odüsszeusz zeneileg rokon záró monológja („no, non sono le Furie ad avventarsi”), a Poszeidón hatalmát megidéző zenekari részlet a Pénelopé és Odüsszeusz találkozását megjelenítő zenekari betét szimmetrikus megfelelője, ahogy Nauszikaá labdajáték-jelenete is rokonítható Melanthó bizarr (halál)táncának zenei megformálásával. Az Odüsszeusz-történet központi képe: az íj felajzása zeneileg rajzolódik ki az opera zenei terében. Ez a hangzási struktúrákkal kirajzolt „kép” mintegy vizualizálja magát az operát is, azaz az idő ismét érzékelhető térré válik. S e térszerkezet rejti magában a mű központi szimbólumát, az értelmezhetőség egyik gócát.

Ligeti György $(2010,121$. o.) Webern ötödik bagatelljének kromatikus mezejét analizálva jut arra a fontos következtetésre, hogy Webern ,a szimmetrikusan elrendezett hangközöket aszimmetrikusan vezeti tovább. Zeneszerzői gondolkodásának alapját egy szigorú konstruktív gerinc alkotja, ezt azonban a megkomponált formában elfedik a többé-kevésbé szabadon kialakuló struktúrák. Ez a fajta zeneszerzői munkamódszer se nem eröltetetten rendezett, se nem teljesen kötetlen: a szabadság és a rend szerencsés egyensúlya valósul meg benne". Ligeti felhívja még a figyelmet a belső harmóniai átrétegződések szerepére a harmóniai mezők határain belül és azokat áthágva. Ezt egy remek hasonlattal szemlélteti: a pókháló-effektussal, melynek lényege, hogy egy lazán széthúzott pókhálónak először csak a mintázata torzul, de a szálai nem változnak, ha viszont erősebben húzzuk szét, a szálak is megváltoznak, egyesek elszakadnak, mások 
a szomszéd szálakkal alkotnak gomolyokat. Az új szerkezet szabálytalanságában őrzi az egykori szabályosságot. Weöres atonális-disszonáns jellegü, a kritika által értetlenül fogadott Tizenkettedik szimfóniája pontosan ilyen szövegpókháló: a harmonikus szövegmezőn egyszer csak irdatlan lyukak keletkeznek a szövegtágulás következtében (bővebben ld. Csehy, 2013). Weöresnél is érzékelhető a hagyományos forma, a rejtett szimmetriák (rekonstruálható) rendszere, de a torzulás evidens jelenléte is. A torzulás mértéke azonban nem olyan mértékü, hogy ne lehetne visszakövetkeztetni a „roncsolás” előtti állapotra magára. Weöresnél a nyelv, a forma és a müfaj mítoszáról van szó, azokról az elmosódásoktól, áttűnésekről, áthallásokról, melyek az értelmezhetőség iránti elkötelezettségünk mániákusságának állítanak görbe tükröt. A szöveg teljesen zenei szervezettségü lesz: az értelmi kondicionálás marginalizálódik, illetve asszociatív marad. Maga a költő ezt így összegzi: „Ez öt tételből áll. Nem irodalmi, hanem zenei motívumra épült, nagyon egyszerü motívumra: alma ring az ágon. Ennek variációi és permutációi után végül más szóanyagra porlik szét a vers.” (Weöres, 1993, 307. o.) A versvégi „mágikus négyzet” paródiából könnyen eljutunk Webernig:

sátor

a répa

téved

opera

flótás

Azaz:

sator

arepo

tenet

opera

rotas

Anton Webern Út a tizenkét hanggal való komponáláshoz című híres, 1932. március 2-án megtartott előadásának végén is felbukkan a mágikus négyzet, hiszen ebből a kubusból kiolvasható a tizenkétfokú technika lényege maga: a sor (Reihe), a tükörfordítás, a rákfordítás és a tükör-rákfordítás egyenértéküsége. Maga Webern $(1965,99-100$. o.) is felhívja a figyelmet a dodekafón komponálás, illetve a szerializmus egyes technikáinak irodalmi gyökérzetére: ,...ez nem csak a zenében van így. Analógia erre a nyelv. A legnagyobb lelkesedéssel töltött el, hogy Shakespeare-nél a szókezdő hangokban és rímekben szintén ilyen összefüggések vehetők észre. Sőt még rákfordítású mondat is akad”.

A mágikus négyzet roncsolt szövegtere mintegy „,megfejtése” lesz a Weöres-vers zenéjének. Mágikus karakterü képi forma megzenésítésére példa Magolcsay Nagy Gábor egyik mandalájának Hérincs Dániel általi zenébe írása: a mandala körformája és a kvintkör adta hasonlósági analógia generálja azt a variációsorozatot, mely a szavak variálható hangtestének kapcsolódási lehetőségeit determinálja, s a kör szabályos terében lezajló mozgások analízisévé válik. ${ }^{2}$

James Dillon (2009) Philomela címü operájában a hang képpé válása különösen eröteljes térpoétikát valósít meg. A főhősnőt megerőszakolása után megfosztják a nyelvétől, így az éneklésre is képtelenné válik, márpedig az éneklés az opera elemi létmódja. A nyelv kitépése, a nyelvtől való megfosztottság allegorikus értelmet nyer: a létezés szótlanná tétele, a verbális halál nem feltétlenül zárja le a kommunikációs lehetőségeket, és korántsem jelenti a történetmesélés végét. A hang képpé alakulása lényegi átváltozás a hatalmas ívű átváltozás-történetben, melyet az artikulált vagy artikulálatlan hang és a 
csönd vagy a csönd felé tartó hörgés kidolgozott ellentéte mélyít tovább. „Philomela, a dalok szerelmese, nem képes énekelni, s így a kifejezés új formáit kellett felfedezni" - írta a zeneszerző, s e bizarr helyzet egyszersmind kitágítja az opera különleges hangzásvilágának lehetőségeit, mely kivált a nyelv kivágása utáni tátogó, elektronikus hangfoszlányok bejátszásával kiegészített tercettben akkumulálódik. A darab egyik kulcsképe a „szövőszék”, mely önálló zenei nyelvet kap, s ez a metaforikus tárgy valóságos emblémaként uralni kezdi a darabot. Philomela a nyelvét keresi, és így énekel: „Ó, anyám, hol van az én nyelvem? A mindent elnyelő tiszta ür hüvelyében." A nyelv nélküli éneklés, a nyelv függetlenedése és feloldódása a semmiben a szöveg, a zene, a szövet materialitásának elemi nyügét érzékelteti.

A zene térré és a tér zenévé transzformálásának számos módját ismerjük: a fenti eszmefuttatás természetesen csak vázolni képes a probléma lényegi vonásait. A konkrét térrel dolgozó, azt a formába applikáló zenei megoldások mellett az imaginárius és metaforikus terek jelentésteremtő ihleterejét lehetetlen nem figyelembe venni még akkor is, ha a zenetörténet hosszabb, klasszikus vonulata (leszámítva a színházi teret) a zenét elsősorban az idő és az időtlenség dimenziói felől gondolta el.

\section{Irodalomjegyzék}

Cage, J. (1994): Üres értelem. In: uő: A csend. Válogatott írások. Jelenkor, Pécs. 199.

Csehy Zoltán (2013): Lapok egy égő partitúrából. Weöres Sándor néhány esete a disszonanciával, az atonalitással és a hagyomány zenei kisiklatásával. Irodalmi Szemle, 56. 8. sz. 17-33.

Dallapiccola, L. (2003): Ulisse. Naive (V 4960).

Dillon, J. (2009): Philomela. Aeon (AECD 0986).

Feldman, M. (2000): Neither. Col legno (WWE 20081).

Kodaj Dániel (2005): Értelem szövedéke, hangok. Feminista és posztmodern olvasatok az amerikai új zenetudományban. Replika, 8. 49-50. sz. 131.

Ligeti György (2010): A tér szerepe a mai zenében. In: uő: Válogatott írásai. Rózsavölgyi, Budapest. 184-189.

Ligeti György (2010): Új notáció - kommunikációs eszköz vagy öncél? In: uö: Válogatott irásai. Rózsavölgyi, Budapest. 197-209.

Ligeti György (2010): Webern harmóniavilága. In: uő: Válogatott írásai. Rózsavölgyi, Budapest. 121.
Pongrácz Zoltán (1971): Mai zene, mai hangjegyírás. Zeneműkiadó, Budapest.

Salonen, E.-P. (2005): Wing on Wing. Deutsche Grammphon (0289 47753759 GH).

Schonberg, H. C. (2006): A nagy zeneszerzök élete. Európa, Budapest.

Stockhausen, K. (1992): Samstag. Stockhausen Verlag (CD 34 A-D).

Varga Bálint András (1986): 3 kérdés 82 zeneszerző. Zeneműkiadó, Budapest.

Webern, A. (1965): Előadások, levelek, írások. Zenemükiadó, Budapest. 73-100.

Weöres Sándor (1993): A szimfóniákról, az elfelejtett versekről. Czigány György rádióbeszélgetése Weöres Sándorral. In: Domokos Mátyás (szerk.): Egyedül mindenkivel. Weöres Sándor beszélgetései, nyilatkozatai, vallomásai. Szépirodalmi, Budapest.

Works by Kurtág Görgy. (1995) Hungaroton, Budapest (HCD 31290).

Wörner, K. H. (2007): A zene története. Vivace, Budapest.

\section{Jegyzetek}

${ }^{1}$ A mủ ebben a változatban nem jelent meg hanghordozón, ám a Kelly-versekre írt dalok és a Matthew Shepard halálát elbeszélő dal hozzáférhetők a Secret music címü, 2001-ben megjelent Del Tredici-CD-n, mely a CRI gondozásában látott napvilágot (878). A Kelly-versek a Brother, a Shepard-dal a Three baritone songs címủ sorozatban lelhetők föl. A Jaime Manrique versére komponált dalt Chris Pedro Trakas énekli, zongorán mindkét esetben maga a zeneszerző kísér. Az Acrostic song számos CD-n és számos változatban meghallgatható: a legszebb felvétel Solti
György és Barbara Hendricks nevéhez füződik (Final Alice, Decca, 1981, 442 9955), de hozzáférhető pl. a Coro kiadásában megjelent Samuel Barber: Agnus dei. An American collection címü 2005-ben kiadott albumon (16031), vagy a Crystal gondozásában 1995-ben megjelent Bach and noodles címün (657) is pl. szaxofon és zongora változatban.

${ }^{2}$ A mủ prezentációja a debreceni KULTmühelyek Országos Konferenciájának Irodalom és interdiszciplinaritás címü ülésszakán hangzott el. 